Utah State University

DigitalCommons@USU

\title{
Effects of fertilization on Hypoxylon canker of trembling aspen
}

\author{
G.E. Teachman \\ D.J. Frederick \\ W.E. Perkis \\ M.F. Jurgensen
}

Follow this and additional works at: https://digitalcommons.usu.edu/aspen_bib

Part of the Forest Sciences Commons

\section{Recommended Citation}

Teachman, G.E.; Frederick, D.J.; Perkis, W.E.; and Jurgensen, M.F., "Effects of fertilization on Hypoxylon canker of trembling aspen" (1980). Aspen Bibliography. Paper 4502.

https://digitalcommons.usu.edu/aspen_bib/4502

This Article is brought to you for free and open access by the Aspen Research at DigitalCommons@USU. It has been accepted for inclusion in Aspen Bibliography by an authorized administrator of DigitalCommons@USU. For more information, please contact

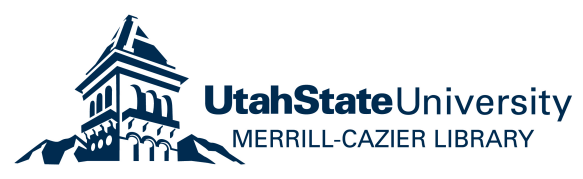




\section{Effects of Fertilization on Hypoxylon Canker of Trembling Aspen}

GEORGE E. TEACHMAN, Soil Scientist, Michigan Department of Natural Resources, Mt. Pleasant 48858; DOUGLAS J. FREDERICK, Associate Professor, School of Forest Resources, North Carolina State University, Raleigh 27650; and WILLIAM E. PERKIS, Graduate Assistant, and MARTIN F. JURGENSEN, Professor, Department of Forestry, Michigan Technological University, Houghton 49931

\section{AMSTMACT}

TEACHMAN, G. E., D. J. FREDERICK, W. E. PERKIS, and M. F. JURGENSEN. 1980. Effects of fertilization on Hypoxylon canker of trembling aspen. Plant Disease 64:284-286.

Aspen (Populus tremuloides) on two sites in Michigan were fertilized in May 1977, then inoculated with Kypoxylon mammatum in June; canker incidence and length were recorded in August and October. Incidence was highest and average length greatest in August for both sites, although the relationship among fertilizer treatments varied. Canker incidence was not independent of fertilizer treatment in August but was in October. There was no significant difference between incidence level in August and October on either site, even though the number of cankers declined for nearly all treatments. Canker length declined from August to October for all treat ments except $\mathrm{K}$, NK, and $P K$, but the decrease was not sigtificant. No significant differences in canker incidence or length and fertilizer treatments between sites were observed. N fertilizer favored Hypoxylon infection and canker development during the summer, whereas $P$ and $K$ treatments restricted canker incidence and development.

Trembling aspen (Populus tremuloides Michx.) is widely distributed and comprises the largest wood volume in the Lake States (12). Hypoxylon canker, caused by Hypoxylon mammatum (Wahl.) Mill. $(=H$. pruinatum [Klot.] Cke.), is the most serious disease of trembling aspen in the Lake States and accounts for a yearly loss of 8.4 million $\mathrm{m}^{3}$ of wood. This mortality approaches the net annual aspen growth of 9.3 million $\mathrm{m}^{3}(17)$.

Aspen mortality and prevalence of Hypoxylon canker have been correlated with many stand and site variables (1 $4,7,13,14,16)$. Early sudies by Gruenhagen (14) and Lorenz and Christensen (16) indicated aspen growing on "poor" quality sites showed a greater incidence of canker infection than those growing on "good" sites. Conversely, later investigators $(1,3,13)$ found no relationship between canker incidence and site quality, site index, or tree vigor.

Bagga and Smalley (5) reported that fertilized, moisture-stressed greenhousegrown aspen cuttings had a lower canker incidence than unfertilized, nonmoisturestressed controls, but this relationship has never been tested in the field. Because operational fertilization of forest stands in the Lake States may increase in the future, we initiated a field study to determine the effects of various fertilizer

Present address of third author: Soil Scientist Salute Inc.. Columbia. MD.

Acepted for publication 16 Oetober 1979

00191-2917/80/03028403/\$03.00/0

1980 American Phytopathological Socioty treatments on the incidence and development of Hypoxylon canker on young aspen.

\section{MATERALS AND METHODS}

Two naturally occurring 4-yr-old aspen clones resulting from clear-cutting of mature aspen stands in Ontonagon County, Michigan, were selected in the spring when time of leaf flush, flowering, leaf morphology, and bark characteristics could be used for clone delineation (8). Clone uniformity was necessary because clones vary in growth response to fertilizers (21) and in susceptibility to disease (20). The first stand (site l) was located on a coarse sand (Rosseau series) and the second (site 2), on a loamy fine sand (Wallace series). Both soils were classed as typic haplorthods. Rainfall and temperature data for the study area were obtained from the U.S. Forest Service, Kenton Ranger Station, approximately $16 \mathrm{~km}$ from the study sites

A randomized block fertilizer trial, with blocking done by site, was established in a uniform part of each stand. Each block contained nine treatment plots each covering $232 \mathrm{~m}^{2}$. Fertilizer tratments applied to each block included $N, P, K, N P, N K, P K$, NPK, and $C a$; the ninth plot served as a control. Fertilizer rates were $225 \mathrm{~kg} / \mathrm{ha}$ of $\mathrm{Nas} \mathrm{NH}_{4} \mathrm{NO}_{3}, 112 \mathrm{~kg} /$ ha of $\mathrm{Pas}$ triple superphosphate, $112 \mathrm{~kg} /$ ha of muriate of potash, and $2,224.5 \mathrm{~kg} / \mathrm{ha}$ of lime. Fertilizers were broadeast by hand in May 1977 before leaf initiation.

Before fertilization, soil physical and chemical properties were determined for each site. With a $2.5 \mathrm{~cm}$ diameter soil probe, 21 sample cores were randomly collected within each treatment plot to a depth of $1 \mathrm{~m}$. Cores were separated by horizon and randomly grouped into three composite samples of seven samples per treatment plot. Soils were analyzed for texture, moisture-holding capacity, organic component, exchangeable, $K$, Ca, $M g$, available $P$, total $N$, and available $\mathrm{N}$ as $\mathrm{NH}+$ and $\mathrm{NO}_{3}$.

During June 1977,10 trees per fertilized treatment ( 90 trees per site) were randomly selected and inoculated with $H$. mammanum at a height of $1 \mathrm{~m}$. The culture was isolated from a nearby stand of naturally infected aspen and was identified by J. D. Rogers of Washington State University, Pullman.

The bark of each tree was surfacedisinfected with a $70 \%$ solution of ethyl alcohol and bruised with a hatchet (14). A $12-\mathrm{mm}^{2}$ circular plug was removed from the bark through to the xylem, and a slightly smaller plug from a 10-day-old $H$. mammatum culture grown on $2 \%$ malt agar was inserted. An equal number of control trees at each site were similarly inoculated with sterile $2 \%$ malt agar plugs. All plugs were covered with three to four layers of Parafilm to prevent tissue drying. At the end of $6 \mathrm{wk}$ and 14 $w k$, each inoculated tree was visually inspected for canker incidence. If infection was observed, vertical canker length was measured and reisolation of H. mammatum attempted.

One-way analysis of variance was done to determine treatment effects on canker incidence; a chi-square test was used to determine if the number of cankers was significantly different at $6 \mathrm{wk}$ and $14 \mathrm{wk}$. A test with unpaired plots was used to determine if canker lengths were significantly different at $6 \mathrm{wk}$ and $14 \mathrm{wk}$.

\section{RESULTS}

The relationship between $H$. mammatum incidence, fertilizer treatment, and measurcment time varied (Table 1). By August, 6 wk after inoculation, the incidence of cankers on site I was highest with fertilizer treatments that included $N$, with the exception of $\mathrm{NK}$. Incidence was lowest with $\mathrm{P}, \mathrm{K}$, or $\mathrm{Ca}$ treatment; the incidence was lower with these treatments than in the control. On site 2, treatments with the highest incidence were NK and $\mathrm{Ca}$ and those with the lowest were NPK, $P$, and $K$; incidence was higher in the control than with the latter three treatments. On both sites, cankers developed on approximately half of the 


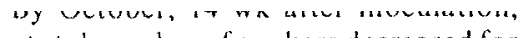
the total number of cankers decreased for all treatments on both sites with the exception of the $P$ treatment on site 1 . which remained the same, and the $P K$ treatment on site 1, which increased by one. The incidence was highest with the $P K$ treatment on site 1 , followed by the $N$ and NPK treatments, and lowest with the $\mathrm{Ca}$ and $\mathrm{K}$ treatments. On site 2, cankers were not evident with the NPK treatment; incidence was highest with the $N$ treatiment.

One-way analysis of variance indicated that canker incidence was not independent of treatment in August but was in October. Chi-square analysis showed no significant difference between the incidence in August and that in October, even though the number of cankers declined for nearly all treatments. Further, no significant difference in canker incidence and fertilizer treatments between siges was noted.

Trends in average canker length were similar to those for canker incidence, declining between August and October (Table 2). A t test for unpaired plots run for each treatment showed that the decline in canker length from August to October was not significant. One-way analysis of variance done for each measurement period showed no significant difference in average canker length between treatments for either August or October. likewisc, no significant difference was noted in canker lengthand fertilizer treatments between sites

Analysis of soil samples from each site did show differences between sites, with a general low fertility level for both. Soil on site 1 was of coarser texture and had lower nutrient levels and moistureholding capacity than that on site 2 . However, moisture content in the major rooting zone ( $A_{2}$ and $B_{21}$ hr horizons) never reached the permanent wilting point throughout the observation period on either site. During July and August, the U.S. Forest Service weather station at Kenton recorded more than $23 \mathrm{~cm}$ of rain, which was approximately $130 \%$ above the previous $10-y r$ average.

\section{DISCUSSION}

Although not statistically significant, $\mathrm{N}$ fertilization seemed to favor Hypoxylon infection during the summer, whereas $P$ and $K$ treatments restricted incidence The same pattern was observed in the results of average canker length from the two sites and may be due to the nutrient imbalance caused by fertilizing with only one element. Generally, canker incidence was higher and canker length was longer with the combination fertilizer treatments than with the $P, K$, or $N$ treatment. An overabundance of $N$ in relation to $P$ and $K$ increases the supply of amino acids relative to that of carbohydrates (18). This may increase tissue succulence

\begin{tabular}{cccccccccccc}
\hline & \multicolumn{1}{c}{ Number of tres with cankers, according to treatment } \\
\cline { 3 - 12 } Site & Month & N & P & K & NP & NK & PK & NPK & Ca & Control & Total \\
\hline 1 & August & 8 & 3 & 4 & 6 & 4 & 6 & 8 & 2 & 5 & 46 \\
& October & 4 & 3 & 2 & 3 & 3 & 7 & 4 & 1 & 3 & 30 \\
2 & August & 6 & 3 & 3 & 6 & 7 & 5 & 2 & 8 & 4 & 44 \\
& October & 5 & 2 & 2 & 4 & 4 & 4 & 0 & 4 & 2 & 27 \\
\hline
\end{tabular}

Table 2. Average lengths (mm) of Hypoxylon cankers on trembling aspen clones according to fertilizer treatment

\begin{tabular}{|c|c|c|c|c|c|c|c|c|c|c|}
\hline \multirow[b]{2}{*}{ Month } & \multirow[b]{2}{*}{ Site } & \multicolumn{9}{|c|}{ Treatment } \\
\hline & & $\mathrm{N}$ & $\mathrm{P}$ & $K$ & NP & NK & PK & NPK & $\mathrm{Ca}$ & Control \\
\hline August & 1 & 22 & 8 & 7 & 21 & 10 & 20 & 24 & 5 & 17 \\
\hline October & 2 & 21 & 8 & 9 & 18 & 26 & 14 & 8 & 19 & 8 \\
\hline \multicolumn{2}{|c|}{ Average } & 21.5 & 8 & 8 & 19.5 & 18 & 17 & 16 & 12 & 12.5 \\
\hline August & 1 & 13 & 8 & 6 & 13 & 12 & 30 & 13 & 3 & 12 \\
\hline October & 2 & 21 & 6 & 7 & 12 & 16 & 12 & 0 & 12 & 5 \\
\hline \multicolumn{2}{|c|}{ Average } & 17 & 7 & 6.5 & 12.5 & 14 & 21 & 6.5 & 7.5 & 8.5 \\
\hline
\end{tabular}

(which presumably facilitates pathogen entry), favor the production of complex nitrogen sources required by the pathogen, or reduce the level of some metabolite produced by the plant that inhibits the parasite (15).

High levels of $P$ and $K$ tend to decrease disease susceptibility by altering the $N$ balance in plants (19). We round, however, that plots with high levels of $P$ and $K$ (PK treatment) in relation to $N$ had both a high disease incidence and aboveaverage canker length at the end of the growing season. This may have been influenced by differences in the natural susceptibility of the two clones that were tested.

Disease incidence and canker length data for October were not as striking as those for August and did not corroborate the greenhouse results of Bagga and Smalley (6), who reported that, under similar soil moisture levels, unferrilized plants were more susceptible than fertilized plants. Two reasons are postulated for these differing results. In past studies of Hypoxylon canker, investigators frequently applied massive amounts of inoculum to test trees to assure infection. We wanted to insure that the host would become infected and yet have the potential to overcome the pathogen as the various fertilizer treatments altered the tree s physiological balance. Consequently, we used a small amount of inoculum to best elucidate fertilizer treatment effects.

Lack of host moisture stress also may account for some of our differing results. Other investigators $(6,13)$ have found that moisture stress in the plant tends to promote infection. In studies with various ascomycete bark cankers, Bier (9-11) reported that low bark turgidity level is influenced to a large degree by the amount of water available in the soil. Bruck (13), working with Hypoxylon canker in New York, found that any factor contributing to soil moisture availabilty and retention showed a strong negative correlation to disease incidence. The strongest relationship in his study was total moisture received during the growing season, and he further concluded that canker incidence was not influenced by a single variable but rather by an array of interacting environmental factors, including site fertility. Our sites had abundant moisture throughout the infection period; presumably, the lack of moisture stress made the sample trees less susceptible to infection.

Another factor bearing on our results was that the trees were young aspen suckers and probably were still interconnected through the parental rootstock. Nutrient translocation between sprouts on differem fertilizer plots was possible, therefore, and could have masked the treatment effects expected for independently growing seedlings.

Our field study has not supported substantial reduction of Hypoxylon canker incidence in young aspen by fertilization. Susceptibility to the disease can be altered by fertilization, but plant moisture stress during a given year, aspen clonal variation, and other factors may negate or confound fertilization effects.

\section{LITERATURE CITED}

1. ANDERSON, R. L. 1952. Factors influencing the incidenee of llypoxylon canker of aspen. Phytopathology $42: 463$

2. ANDERSON.R. 1. 1953. Hypoxylon canker of aspen in the Lake States. U.S. For. Servlake States For. Exp. Stn. Tech. Note 400. I p.

3. ANDERSON, R. L. 1964. Hypoxylon canker impact on aspen. Phytopathology 54:253-257.

4. ANDERSON, G. W., and R. L. ANDERSON. 1968. Relationship between density of quaking aspen and incidence of Hypoxylon canker. For. Sci $14: 107-111$

5. BACB(iA D) K , and E. B. SMALLEY 1974. The development of Hypoxyion canker of Populus tremuloides: Role of ascospores, conidia, and toxins. Phytopathology 64:654-658.

6. BAGGA, D. K. and E. B. SMALLEY. 1974 The development of Hypoxylon canker of Populus tremuloides: Role of interacting 


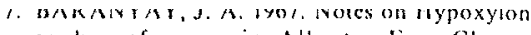
canker of aspen in Atberta. For. Chron 125:372-380.

8. BARNES, B. V. 1966 . The clonal habit of American aspen. Ecology 47:439-447.

9. BIER, J. E. 1959. The relation of bark moisture to the development of canker diseases caused by native faculative parasites. 1. Cryptodiaporthe casker on willow. Can. J. Bot 37:229-2.38.

10. BIER, J. E. 1959. The relation of bark moisture to the development of canker diseases caused by native facultative parasites. II. Fusarium canker on black willow. Can. J. Bot. 37:781-788.

11 BIER J E 1959 . The relation of bark moisture to the development of canker diseases cansed by native faculative parasites. III. Cephalosporium canker on western hemlock. Can. I Bot.
Quaking aspen: sluves and management in the l.ake Stales. U.S. Dop. Agric Agric. Handb. 486 S2 pp.

13. BRUCK, R. I. 1978, Interacting environmenta factors associated with the incidence of Hypoxylon canker on trembling aspen. Ph.D. thesis, State Univ. New York, Syracuse. 80 pp.

14. GRUENHAGEN, R. H. 1945. Hypoxylon pruinatum and its pathogenesis on poplar Phytopathology 35:72-89.

15. HARE, R, C. 1966. Physiology of resistance to fungal diseases in plants. Bot. Rev. 32:95-137.

16. LORENZ, R. C., and C. M. CHRISTENSEN 1937. A survey of forest tree diseases and their relation o sand improvement in the 1 ate and CentralStates. U.S. Dept. Agric. Bur. Plant Ind Publ., Washington, DC. $\$ 2$ pp.
Pages $21-26$ in: Proc. Aspen Symposium. U.S For. Serv. Gen. Tech. Rpt. NC-1.154 pp.

18. MEYER, B. S. D. B. ANDERSON, R H BOHNINB, and D. G. FRATIANNE. 1963. Introduction to Plant Physiology. D. Van Vostrand Co., New York. $540 \mathrm{pp}$.

19. TROLLDENIER, G. 1969. Cercal discases and plant nutrition. Pot. Rev. 23/34:1-16

20. VALENTINE, F. A..D.P. MANION and $X . E$ MOORE. 1976. Genetic control of resistance to Hypoxylon infection and canker development in Populus tremuloides. Pages 132-146 in: Proc. 12 th lake States For. Tree Improv. Conf. U.S For. Serv. Gen. Tech. Rp1. NC:26. $206 \mathrm{pp}$

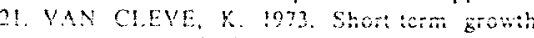
responses to rertilization in young quaking aspen. J. For. 71:758-759.

\section{Geneva Leaf-Wetness Detector}

C. A. SMITH, Research Support Specialist, and J. D. GILPATRICK, Associate Professor, Department of Plant Pathology, New York State Agricultural Experiment Station, Cornell University, Geneva, NY 14456

\section{ABSTRACT}

SMITH. C. A. and J. D. GILPATRICK. 1980. Geneva leaf-wemess detector. Plant Discase 64: $286-288$.

An electronic instrument that measures the incidence and duration of lear wetness, ie, free water on leaf surfaces, needs only a low power supply and may also be used to activate other devices, such as spore traps. Leaf wetness can be recorded on a modified weather-recording instrument, such as a bygrothermograph, or used on-line in a disease-forecasting computer program. The Geneva instrument compared favorably with the deWit detector in measuring leaf wetness in apple orchards and bean ficlds.

Many important airborne fungal pathogens of foliage depend on free moisture on the host surface for the infection process. Control of these diseases with after-infection fungicides (curative treatments) requires accurate recording of prior host surface wetting. For example, timing of after-infection fungicide sprays to control apple scab, caused by Venturia inaequalis (Cooke) Wint, has been based primarily on Mills" periods, which estimate infection periods as a function of leaf-wetness duration and temperature (2). Improvements in scab control by fungicides requires more precise estimates of leaf wetting than is possible by visual observation of the beginning of rain and the ending of leaf wetting. Automatic recording of the duration of leaf wetness by electronic instruments would provide reliable information on leaf wetness for integration into on-line pest management programs.

Commercial instruments are available for recording time and temperature or time and surface wetness, and at least one

Acepted for publication 22 Oorober 1979.

00191-291.7/80/03028603/\$03.00/0

(1980 American Phytopathological Society records all three simultancously (3). The object of our research was to develop for ficld use an instrument that is reliable. accurate, simple, small, lightweight, inexpensive battery-operated, and easy to read and interpret. The option of linking the instrument to a computer for rapid analysis of leaf-wetting periods or to activate other devices such as spore traps was also desired.

\section{MATERIALS AND METHODS}

We evaluated several leaf-wetness measuring instruments, including the deWit 7-day recorder, which utilizes a hemp string as a wetness sensor; a circular glass plate fitted with an indelible pencil that writes on the rotating plate when the surface is wet (4); and some electronic devices of our own design. Electronic instruments met our criteria best, and we studied several variations of sensors, circuitry, power supply, and recorders. The Geneva leaf-wetness detector is the most satisfactory model developed by us to date.

Apparatus. The device records the presence or absence of free moisture on the surface of a simulated leat sensor. The sensor is placed at the focation where leaf wetness is to be monitored and is connected to the detector circuitry, an event recorder, and a $12-\mathrm{V}$ direct-current power supply (Fig. 1). At programmed intervals, current is allowed to flow momentarily to the sensor. If the sensor is wet, the current continues to the event recorder, where a pen arm is activated and wetness is recorded on a chart. If the sensor is dry, current does not flow to the recorder and no welness is recorded.

The leaf-wetness sensor, which acts as the leaf simulator, consists of a $0.25-\mathrm{mm}$ $(0.01$-in.) gold-plated printed circuit grid plate (Wong Laboratories, Cincinnati, OH 45209) coated with (wo thin layers of latex paint. The sensor is similar to that of Davis and Hughes (1). Wet and dry conditions are determined by measuring the resistance across the grid plate. When moisture is absent, resistance is very high and electricity cannot flow across the grid. When moisture is present, resistance drops to a low level, enabling current to pass through to the second half of the circuitry. The installation of a 20,000ohm variable resist or between the sensor return line and ground enables the on-off actions of the sensor to be recorded at a specific resistance level. Further details about the design of the electronic components (Fig. 2) are available from the authors.

Recording devices. Leaf wetness is recorded on a standard thermograph modified with an additional pen for this purpose. A Bendix-Friez (The Bendix Corp., Baltimore, MD 21204) and Weather Measure (Sacramento, CA 95841) thermograph or hygrothermograph were the easiest to adapt. In addition to providing time, temperature, and humidity data, these units are constructed so that a wetness pen assembly can be mounted. Other types of instruments have limited mounting space or features 